\title{
Urea uptake by the marine bacterium Deleya venusta HG1
}

\author{
THOMAS JAHNS* \\ 13.3 Fachrichtung Mikrobiologie, Universität des Saarlandes, Im Stadtwald, D-W-6600 Saarbrücken, Federal Republic \\ of Germany
}

(Received 22 April 1992; revised 12 June 1992; accepted 19 June 1992)

\begin{abstract}
The uptake (transport and metabolism) of urea was studied in a strain of the marine bacterium Deleya venusta, measuring the uptake of $\left[{ }^{14} \mathrm{C}\right]$ urea in vivo and the urease reaction in vitro. Urea uptake in vivo was sodiumdependent and exhibited a $K_{\mathrm{m}}$ value of $1.4 \mu \mathrm{M}$ for urea, a broad pH optimum between pH 6.0 and 8.5, a distinct temperature optimum at $35^{\circ} \mathrm{C}$ and a requirement for energy. Urease activity in vitro exhibited a $K_{\mathrm{m}}$ value of $0.86 \mathrm{mM}$ for urea and showed maximum activities at $\mathrm{pH} 8.5$ and $60^{\circ} \mathrm{C}$; the enzyme was neither dependent on the presence of sodium, nor inhibited by metabolic inhibitors. Synthesis of the urea uptake system was subject to nitrogen control; ammonium resulted in a repression of the system, whereas high uptake rates were observed after growth with nitrate or incubation of the cells in the absence of a nitrogen source. The uptake reaction in vivo, but not the urease activity in vitro, was decreased greatly in the presence of ammonium. This inhibition was relieved by methionine sulphoximine (MSX), a potent inhibitor of glutamine synthetase; in mutant strains impaired in this enzyme no inhibition of urea uptake by ammonium was observed. These results suggest that glutamine formed from ammonium rather than ammonium itself regulates urea uptake activity in $D$. venusta.
\end{abstract}

\section{Introduction}

The importance of urea as a nitrogen source in the marine environment has been pointed out in numerous publications during the last 20 years (Remsen, 1971; Herbland, 1976; Kristiansen, 1983; Lund \& Blackburn, 1989; Paerl, 1991). It is therefore surprising that whilst several studies describe urea utilization by estuarine and marine micro-organisms (ZoBell \& Feltham, 1935; Taga, 1970 ; Savidge \& Johnston, 1987), there are no reports on the transport of this compound in marine prokaryotes; this may partly be due to the common assumption that there is no need for a specific bacterial permease system for such a small, uncharged molecule. However, the permeability coefficients of bacterial membranes for urea are low (between 2.7 and $4.6 \times 10^{-8} \mathrm{~cm} \mathrm{~s}^{-1}$; Jahns et al., 1988), and ambient urea concentrations in, for example, marine environments rarely exceed the micromolar range (Remsen et al., 1974). Energy-dependent uptake systems for urea have been reported in freshwater and marine algae (Syrett \& Bekheet, 1977; Williams \&

* Tel. $6813022745 ;$ fax 6897798181 .

Abbreviations: MSX, methionine sulphoximine; GS, glutamine synthetase; CCCP, carbonyl cyanide $m$-chlorophenylhydrazone; DCCD, dicyclohexylcarbodiimide.
Hodson, 1977; Rees et al., 1980), yeasts and other fungi (Cooper \& Sumrada, 1975; Pateman et al., 1982) and several non-marine bacteria (Jahns et al., 1988). In this paper, some properties of the urea uptake system in a strain of a newly isolated marine bacterium and its regulation, both of synthesis and activity, are described.

\section{Methods}

Media and growth conditions. Deleya venusta strain HG1 was grown at $26^{\circ} \mathrm{C}$ and $\mathrm{pH} 7.5$ in a mineral medium (Schlegel et al., 1961) containing $500 \mathrm{mM}-\mathrm{NaCl}, 0.5 \%(\mathrm{w} / \mathrm{v})$ glucose and the nitrogen sources indicated in the experiments. Unless otherwise indicated, cells were harvested at the end of exponential growth, washed twice in $50 \mathrm{mM}$-phosphate buffer $\mathrm{pH} 7.5\left(31 \mathrm{~mm}-\mathrm{KH}_{2} \mathrm{PO}_{4}, 19 \mathrm{mM}-\mathrm{Na}_{2} \mathrm{HPO}_{4}\right)$ containing $500 \mathrm{~mm}$ $\mathrm{NaCl}$, resuspended in the same buffer containing $0.5 \%$ glucose and stored on ice for up to $4 \mathrm{~h}$ before the uptake experiments were performed. The optical density of the cell suspensions was measured at $436 \mathrm{~nm}$.

Isolation of mutants. Mutants lacking glutamine synthetase (GS; EC 6.3.1.2) activity were isolated on the basis of their inability to grow with low concentrations of urea as the nitrogen source. A mutagenesis procedure using ethylmethanesulphonic acid was employed as previously described (Jannsen et al., 1981), with the following modifications: carbenicillin was replaced by ampicillin $\left(50 \mu \mathrm{g} \mathrm{ml}^{-1}\right)$; in the counterselection step, $0.5 \mathrm{~mm}$-urea was used instead of glutamate and ammonium sulphate, and surviving cells were grown in a mineral medium supplemented with $1 \mathrm{~mm}$-glutamine and $5 \mathrm{~mm}$-ammonium chloride. 
Uptake experiments and enzyme activities. Cells suspensions adjusted to $\mathrm{OD}_{436}$ values between 0.3 and 1.0 were incubated at $30^{\circ} \mathrm{C}$ for $5 \mathrm{~min}$ prior to addition of $\left[{ }^{14} \mathrm{C}\right]$ urea; uptake was measured as previously described (Jahns \& Kaltwasser, 1989) by following the decrease of the $\left[{ }^{14} \mathrm{C}\right]$ urea concentration in the suspending medium. Disintegration of the cells was achieved by ultrasonic treatment with a Branson B12 sonifier at a maximum output of $70 \mathrm{~W}$. Enzyme activities were determined in the cell-free supernatant, obtained by centrifugation of the sonified cell suspensions at $4{ }^{\circ} \mathrm{C}$ and $50000 \mathrm{~g}$ for $15 \mathrm{~min}$. Unless otherwise indicated, urease activity (EC 3.5 .1 .5 ) was determined in a buffer containing $100 \mathrm{~mm}$-diethylbarbituric acid and $20 \mathrm{~mm}$-urea at pH 8.5 by the indophenol method according to Zawada \& Sutcliffe (1981), measuring the formation of ammonium from hydrolytic breakdown of urea; for determination of GS activity, the magnesiumdependent synthetic assay or the manganese-dependent transferase assay, both at $\mathrm{pH} 8.2$, were employed as described by Bender et al., (1977), except that the CTAB solution was replaced by distilled water. Urea uptake activity is given in nmol urea taken up (mg protein) $)^{-1} \mathrm{~min}^{-1}$; enzyme activities are given in nmol ammonium (urease) or nmol $\gamma$-glutamylhydroxamate (GS) formed (mg protein) ${ }^{-1}$ $\min ^{-1}$.

Determination of protein, urea and ammonium. Ammonium was determined by the indophenol method (Zawada \& Sutcliffe, 1981); urea was measured by the same method after its hydrolysis to ammonia by the action of jack bean urease. Protein was determined in cell suspensions according to Schmidt et al. (1963), with the modification that only $10 \%$ of the indicated amount of potassium iodide was used, and in cell-free extracts according to the Lowry method; bovine serum albumin was used as a standard.

Reproducibility of results. All results presented are mean values from at least two independent experiments; SD values not exceeding $\pm 20 \%$ of the mean values are not indicated. The Tables and Figures show representative results from single experiments, which were repeated at least once. Experiments for the determination of the $K_{\mathrm{m}}$ value of urea uptake and urease were repeated at least three times; linear correlations were fitted by regression analysis, yielding values for $r$ of between 0.985 and 0.995 .

\section{Results and Discussion}

\section{Isolation and characterization of strain HG1}

The strain under study, designated HG1, was isolated in September 1990 from surface waters of the North Sea in Helgoland, FRG, at a distance of about $500 \mathrm{~m}$ from the coast. The following properties of this bacterium indicate that it belongs to the genus Deleya (Baumann et al., 1983). Growth of the strictly aerobic, Gram-negative rod occurred only in the presence of $\mathrm{NaCl}$ concentrations of $200 \mathrm{mM}$ or more (up to $3000 \mathrm{mM}$, the highest concentration tested, with an optimum at $700 \mathrm{~mm}$ ); $\mathrm{NaCl}$ could not be replaced by other cations such as $\mathrm{KCl}$, $\mathrm{CsCl}$ or $\mathrm{LiCl}$. Electron microscopy revealed that this motile bacterium had peritrichous flagella; poly- $\beta$ hydroxybutyrate [extracted from the cells and identified by the methods of Law \& Slepecky (1961) and
Williamson \& Wilkinson (1958)] was accumulated as a storage compound; D-glucose, D-gluconate and glycerol were readily utilized by this bacterium; these traits differentiate the isolated organism from other aerobic marine species such as Pseudomonas or Alteromonas.

Cell-free extracts from strain HGl were analysed by SDS-PAGE and compared with those of $D$. venusta strain A84 (ATCC 35137), D. cupida strain A79 (ATCC 27124) and D. aesta strain A134 (ATCC 27128) (kindly provided by E. F. DeLong, Woods Hole Oceanographic Institution, MA, USA); practically identical protein patterns for D. venusta A84 (ATCC 35137) and strain HG1 were observed (results not shown). The utilization of maltose and the inability to metabolize D-mannose were further characteristics distinguishing strain HG1 from Deleya species other than D. venusta (Valderrama $e t$ $a l .$, 1991). However, strain HG1 was susceptible to $50 \mu \mathrm{g}$ ampicillin $\mathrm{ml}^{-1}$, in contrast to $D$. venusta strain NCMB 1979 (Valderrama et al., 1991). Interestingly, both strains HG1 and D. venusta strain A84, but not the other species of Deleya investigated, exhibited a strong odour characteristic of fresh peas during growth. The strain has been deposited in the German collection of Microorganisms and Cell Cultures (DSM), Braunschweig, FRG as Delaya venusta HG1 DSM 7049.

\section{Kinetics of urea uptake}

When grown with $10 \mathrm{~mm}$-nitrate as the nitrogen source, $D$. venusta strain HG1 rapidly transported urea. Uptake was a saturable process showing typical MichaelisMenten kinetics, with a $K_{\mathrm{m}}$ value of $1.4 \pm 0.7 \mu \mathrm{M}$ for urea and a $V_{\max }$ of $7.8 \pm 3.0 \mathrm{nmol}$ urea (mg protein) $)^{-1} \mathrm{~min}^{-1}$ $(n=4)$. An affinity about one order of magnitude lower has been described for the urea uptake systems of nonmarine bacteria (Jahns et al., 1988) and fungi (Pateman et al., 1982; Cooper \& Sumrada, 1975). The affinity of the urea uptake system of $D$. venusta strain $\mathrm{HG} 1$ is in the range of that described for several marine algae (McCarthy, 1972), for which $K_{\mathrm{m}}$ values between 0.14 and $0.85 \mu \mathrm{M}$ for urea have been measured. This high affinity may facilitate the utilization of urea at the low concentrations usually occurring in marine systems (Remsen et al., 1974).

The urease of strain HGl exhibited a $K_{\mathrm{m}}$ value of $0.86 \pm 0.23 \mathrm{~mm}$ for urea and a $V_{\max }$ of $497 \pm 142 \mathrm{nmol}$ ammonium (mg protein) $)^{-1} \min ^{-1}(n=5)$ in nitrategrown cells. Maximum uptake activities were observed between pH 6.0 and 8.5 and at $35^{\circ} \mathrm{C}$; urease activity, in contrast, was highest at $\mathrm{pH} 8.5$ and $60^{\circ} \mathrm{C}$ (Fig. 1). Based on temperature-dependence determinations, apparent activation energies of $40.3 \mathrm{~kJ} \mathrm{~mol}^{-1}$ and $86.3 \mathrm{~kJ} \mathrm{~mol}^{-1}$ were calculated from Arrhenius plots for urease and urea uptake, respectively. 


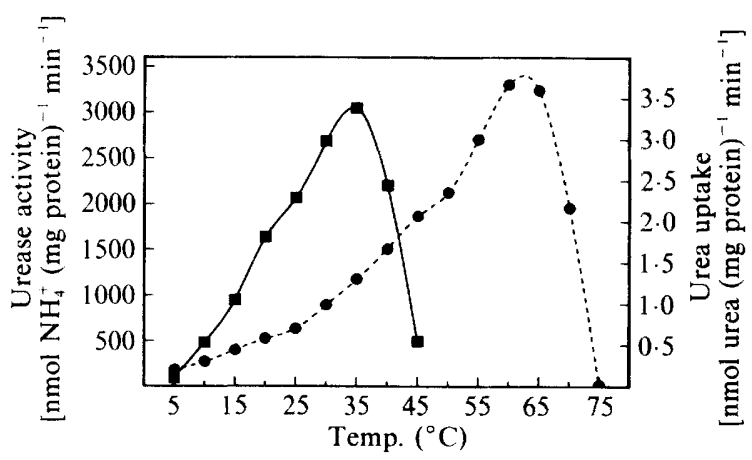

Fig. 1. Temperature-dependence of urease and urea uptake in $D$. venusta strain HG1. Cells grown with $10 \mathrm{~mm}$-nitrate as the nitrogen source were washed twice and incubated at the temperature indicated for $10 \mathrm{~min}$ before uptake was started by addition of $25 \mu \mathrm{M}-\left[{ }^{14} \mathrm{C}\right]$ urea $\left(6 \times 10^{5} \mathrm{~Bq} \mathrm{mmol}{ }^{-1} ; 0\right)$. Similarly, cell-free extracts were incubated for $10 \mathrm{~min}$ at the temperatures indicated prior to the determination of urease activity $(\mathbf{O})$.

\section{Effect of inhibitors on urea uptake}

Urea uptake in D. venusta strain HG1 was an energydependent process, as indicated by the effect of various metabolic inhibitors or by the absence of glucose (Table 1). Azide, cyanide and the protonophore CCCP almost completely inhibited uptake, while the ATPase inhibitor DCCD exerted only a minor effect. These results implied that ATP was not the direct driving force for urea uptake, but that an electrochemical ion gradient provided the energy necessary for the uptake reaction.

Inhibition by CCCP was strongly dependent on the $\mathrm{pH}$ of the assay; at $\mathrm{pH} 7 \cdot 3$, a $95 \%$ inhibition of urea

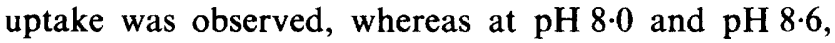
uptake was inhibited by about $70 \%$ and $10 \%$, respectively (results not shown). Similar observations have been described for the inhibitory action of CCCP on amino acid transport in three marine bacteria, in one moderate halophile, and to a lesser extent in Escherichia coli (MacLeod et al., 1988), and have been attributed to the acidic $\mathrm{p} K$ value, about $6 \cdot 1$, of this protonophore. With increasing $\mathrm{pH}$, the proportion of the deprotonated, anionic form of CCCP increases; the anion, however, can cross the membrane at only $1 \%$ of the rate of the protonated, electrically neutral form (Kasianowicz et al., 1984).

None of the inhibitors described exhibited an inhibitory effect on the urease reaction in vitro (data not shown). If passive diffusion were the only mechanism of translocation of urea into the cell, these differences between in vitro urease and in vivo urea uptake, and those between the kinetic parameters as well as the dependence on temperature and $\mathrm{pH}$, would not have been observed. The findings are evidence for the existence of
Table 1. Effect of inhibitors and the lack of an energy source on urea uptake in D. venusta strain HGI

Cells were grown with $10 \mathrm{~mm}$-nitrate. Inhibitors were added $5 \mathrm{~min}$ prior to the addition of $25 \mu \mathrm{M}-\left[{ }^{14} \mathrm{C}\right]$ urea $\left(6 \times 10^{5} \mathrm{~Bq} \mathrm{mmol}^{-1}\right)$. CCCP and DCCD were dissolved in ethanol (final ethanol concentration $1 \%, v / v)$; ethanol alone had no effect. Urea uptake activity is given in nmol urea taken up (mg protein) $)^{-1} \mathrm{~min}^{-1}$.

\begin{tabular}{lcc}
\hline \hline Inhibitor & $\begin{array}{c}\text { Concn } \\
(\mathrm{mM})\end{array}$ & $\begin{array}{c}\text { Urea } \\
\text { uptake }\end{array}$ \\
\hline Control & - & 3.99 \\
Without glucose & - & 0.87 \\
CCCP & 0.02 & 0.55 \\
DCCD & 0.02 & 3.75 \\
Cyanide & 1.0 & 0.16 \\
NaN $_{3}$ & 10 & 0.51 \\
\hline \hline
\end{tabular}

Table 2. Effect of monovalent and divalent cations on urea uptake in D. venusta strain $H G I$

Cells were grown with $10 \mathrm{~mm}$-nitrate as the nitrogen source. For the uptake assay, cells were suspended in $100 \mathrm{~mm}$-Tris/ $\mathrm{HCl}$, pH 7.5 , containing $0.5 \%$ glucose and the compounds indicated; uptake was started by the addition of $35 \mu \mathrm{M}-\left[{ }^{14} \mathrm{C}\right]$ urea $\left(6 \times 10^{5} \mathrm{~Bq} \mathrm{mmol}^{-1}\right)$. Urease activity is given in $\mathrm{nmol}$ ammonium formed (mg protein $)^{-1} \mathrm{~min}^{-1}$; urea uptake activity is given in nmol urea taken up (mg protein) $)^{-1} \mathrm{~min}^{-1}$.

\begin{tabular}{lccc}
\hline \hline $\begin{array}{l}\text { Compound } \\
\text { added }\end{array}$ & $\begin{array}{c}\text { Concn } \\
(\mathrm{mM})\end{array}$ & $\begin{array}{c}\text { Urea } \\
\text { uptake }\end{array}$ & $\begin{array}{c}\text { Urease } \\
\text { activity }\end{array}$ \\
\hline $\mathrm{None}$ & - & $0 \cdot 29$ & 422 \\
$\mathrm{NaCl}$ & 250 & $3 \cdot 59$ & 462 \\
& 500 & $4 \cdot 85$ & 444 \\
& 1000 & $3 \cdot 06$ & 418 \\
$\mathrm{KCl}$ & 500 & $0 \cdot 34$ & 425 \\
$\mathrm{LiCl}$ & 500 & $1 \cdot 50$ & 463 \\
$\mathrm{CsCl}$ & 500 & $0 \cdot 29$ & 443 \\
$\mathrm{MgCl}_{2}$ & 500 & $0 \cdot 33$ & 454 \\
\hline \hline
\end{tabular}

an energy-dependent translocation of urea via a permease system exhibiting a high affinity towards urea, and that the subsequent hydrolysis via urease is a distinct process in D. venusta strain HG1.

\section{Sodium dependence of urea uptake}

The in vivo uptake of urea in $D$. venusta strain HG1 depended on the presence of sodium in the incubation medium; maximum uptake rates were observed at $500 \mathrm{~mm}-\mathrm{NaCl}$, the ambient sodium concentration of seawater. Only negligible amounts of urea were taken up in the absence of sodium, or when it was replaced by other cations (Table 2); only lithium replaced sodium to an appreciable extent. Such a stimulatory influence of 
sodium was not observed for the urease reaction in vitro (Table 2), providing further evidence for the existence of a urea permease in D. venusta strain HGl. A dependence of urea uptake on sodium has also been described for a marine diatom, Phaeodactylum tricornutum (Rees et al., 1980). More experiments would be required to decide whether sodium is directly involved in the uptake of urea via a sodium-ion/substrate symport mechanism in $D$. venusta strain HG1, as shown for the uptake of $\alpha$ aminoisobutyric acid in Alteromonas haloplanktis (Niven \& MacLeod, 1980), or whether urea uptake indirectly depends on the presence of sodium, which may be necessary for transport and/or oxidation of glucose and thus generation of metabolic energy, required for the urea uptake reaction. Such interdependences between sodium-dependent membrane transport and sodiumdependent oxidation of an energy source have recently been described for another species of Deleya, D. aesta strain 134, by Berthelet \& MacLeod (1991).

\section{Regulation of urea uptake activity}

Urea uptake was strongly inhibited by ammonium (Table 3), which delayed the onset of the uptake reaction; this delay was proportional to the amount of added ammonium (results not shown). The possibility that urea and ammonium were taken up by a common transport system exhibiting a higher affinity towards ammonium was ruled out by experiments with methionine sulphoximine (MSX). This compound is known to be a strong inhibitor of GS (Meister, 1974). In D. venusta strain HG1, MSX markedly reduced GS activity in vitro ( $97 \%$ inhibition at a concentration of $5 \mathrm{mM}-\mathrm{MSX}$; results not shown). MSX relieved the inhibitory effect of ammonium on the uptake of urea (Table 3); in the absence of added ammonium, urea uptake was stimulated more than 2-fold by MSX (Table 3). These results indicate that a product formed intracellularly from ammonium in a GS-dependent reaction inhibited the urea uptake reaction. The finding that added glutamine but not glutamate strongly interfered with the uptake reaction (Table 3 ) indicated that glutamine was this inhibitor.

In order to confirm this hypothesis, attempts were made to isolate mutant strains of $D$. venusta strain HG1 lacking GS or with impaired enzyme activity. Eight independent mutant strains that depended on the presence of glutamine in the growth medium were isolated after mutagenesis with ethylmethanesulphonic acid. Two of these mutants, D. venusta strains HG1-II and HG1-V, exhibited less than $1 \%$ of the GS activity measured in the wild-type. An inhibition of urea uptake by ammonium was no longer observed in these strains
Table 3. Effect of ammonium and MSX on urea uptake and urease activity in D. venusta strain $H G 1$

Cells were grown with $10 \mathrm{~mm}$-nitrate as the nitrogen source. Ammonium was added $10 \mathrm{~s}$ prior to the start of the uptake and enzyme assays, while in the experiments with MSX, cells and cellfree extracts were pre-incubated for $30 \mathrm{~min}$ with this inhibitor; uptake was started by addition of $200 \mu \mathrm{M}-\left[{ }^{14} \mathrm{C}\right]$ urea $\left(6 \times 10^{5} \mathrm{~Bq} \mathrm{mmol}^{-1}\right)$. Urease activity is given in $\mathrm{nmol}$ ammonium formed (mg protein) $)^{-1} \mathrm{~min}^{-1}$; urea uptake activity is given in $\mathrm{nmol}$ urea taken up (mg protein) $)^{-1} \mathrm{~min}^{-1}$.

\begin{tabular}{lccc}
\hline \hline Inhibitor & $\begin{array}{c}\text { Concn } \\
(\mathrm{mM})\end{array}$ & $\begin{array}{c}\text { Urea } \\
\text { uptake }\end{array}$ & $\begin{array}{c}\text { Urease } \\
\text { activity }\end{array}$ \\
\hline None & - & $3 \cdot 59$ & 472 \\
MSX & 5 & $7 \cdot 72$ & 459 \\
Ammonium & $0 \cdot 1$ & $0 \cdot 47$ & 480 \\
Glutamine & $0 \cdot 1$ & $0 \cdot 33$ & 467 \\
Glutamate & $0 \cdot 1$ & $3 \cdot 58$ & 478 \\
MSX + & $5+0 \cdot 1$ & $7 \cdot 01$ & 463 \\
ammonium & & & \\
\hline \hline
\end{tabular}

Table 4. GS, urease and urea uptake in D. venusta strain HGI and the mutant strains HGI-II and HGI-V

Cells grown in mineral medium supplemented with $1 \mathrm{~mm}$ glutamine and $5 \mathrm{~mm}$-ammonium chloride were washed twice and incubated for $6 \mathrm{~h}$ in the absence of an added nitrogen source. Urea uptake activity was measured in the presence or absence of $0 \cdot 1 \mathrm{~mm}$-ammonium. GS activity was determined by the magnesium-dependent synthetic assay. Enzyme activities are in nmol $\gamma$-glutamylhydroxamate (GS) and nmol ammonium (urease) formed (mg protein $)^{-1} \mathrm{~min}^{-1}$; urea uptake activity is given in nmol urea taken up (mg protein) ${ }^{-1} \mathrm{~min}^{-1}$.

\begin{tabular}{lrrrr}
\hline \hline \multirow{2}{*}{$\begin{array}{l}\text { D. venusta } \\
\text { strain }\end{array}$} & $\begin{array}{c}\text { GS } \\
\text { activity }\end{array}$ & $\begin{array}{c}\text { Urease } \\
\text { activity }\end{array}$ & $-\mathrm{NH}_{4}^{+}$ & $+\mathrm{NH}_{4}^{+}$ \\
\hline HG1 & 417 & 646 & $6 \cdot 72$ & 0.64 \\
HG1-II & 2 & 739 & $4 \cdot 25$ & $4 \cdot 50$ \\
HG1-V & 2 & 609 & $5 \cdot 47$ & $5 \cdot 22$ \\
\hline
\end{tabular}

(Table 4). These results confirm that it was not the added ammonium which interfered with the uptake of urea in D. venusta strain $\mathrm{HG} 1$, but that the glutamine formed via GS was probably responsible for the observed inhibition of the uptake reaction. A comparable regulatory effect of intracellular glutamine has been discussed for the uptake of ammonium/methylammonium in Klebsiella pneumoniae (Kleiner \& Castorph, 1982), Azotobacter vinelandii (Jayakumar \& Barnes, 1984) and Escherichia coli (Jayakumar et al., 1987).

\section{Regulation of synthesis of the urea uptake system}

When D. venusta strain HG1 was grown with $5 \mathrm{mM}$-urea as sole nitrogen source, ammonium was excreted into the 


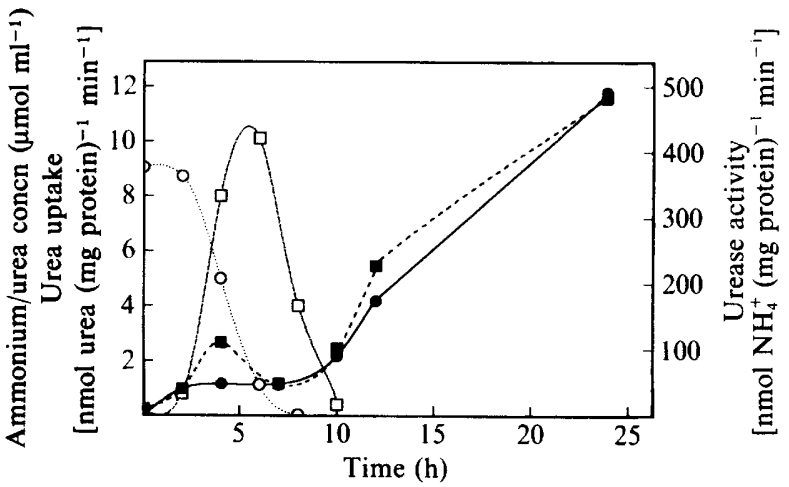

Fig. 2. Urease and uptake of urea in D. venusta strain HG1. Cells grown with $20 \mathrm{~mm}$-ammonium as the nitrogen source were washed twice and resuspended in growth medium containing $10 \mathrm{~mm}$-urea as the nitrogen source. $\square$, Ammonium; $O$, urea; $O$, urease; $\boldsymbol{\square}$, uptake of $25 \mu \mathrm{M}-\left[{ }^{14} \mathrm{C}\right]$ urea $\left(6 \times 10^{5} \mathrm{~Bq} \mathrm{mmol}^{-1}\right)$.

Table 5. Influence of the nitrogen source used for growth on glutamine synthetase, urease and urea uptake activity in D. venusta strain $H G I$

Cells pregrown with $20 \mathrm{~mm}$-ammonium as the nitrogen source were harvested during exponential growth, incubated in growth medium with the nitrogen sources indicated and harvested during exponential growth (cells incubated without a nitrogen source were harvested after $12 \mathrm{~h}$ ) GS activity was determined by the manganese-dependent transferase assay. Enzyme activities are in nmol $\gamma$-glutamylhydroxamate (GS) and nmol ammonium (urease) formed ( $\mathrm{mg}$ protein) $)^{-1} \mathrm{~min}^{-1}$; urea uptake activity is given in nmol urea taken up (mg protein) ${ }^{-1} \mathrm{~min}^{-1}$.

\begin{tabular}{lccc}
\hline \hline Nitrogen source & $\begin{array}{c}\text { GS } \\
\text { activity }\end{array}$ & $\begin{array}{c}\text { Urease } \\
\text { activity }\end{array}$ & Urea uptake \\
\hline Nutrient broth & 16 & 18 & $0 \cdot 0$ \\
$\mathrm{NH}_{4} \mathrm{Cl}(10 \mathrm{mM})$ & 3 & 8 & $0 \cdot 2$ \\
$\mathrm{KNO}_{3}(10 \mathrm{mM})$ & 244 & 354 & $14 \cdot 0$ \\
Urea $(5 \mathrm{mM})$ & 6 & 213 & $1 \cdot 0$ \\
Glutamine (5 mM) & 3 & 99 & $1 \cdot 0$ \\
Without a fixed & 214 & 26 & $16 \cdot 2$ \\
nitrogen source & & & \\
\hline
\end{tabular}

medium, and low rates of urea uptake were observed. The activity of the uptake system increased after both urea and ammonia were exhausted (Fig. 2). Cells grown with nitrate and subsequently incubated in growth media containing $20 \mathrm{~mm}$-ammonium showed a rapid decline of urea uptake activity. In contrast, the transfer of ammonium-grown cells to a growth medium without an added nitrogen source resulted in a rapid increase of the urea uptake rate (data not shown). These observations suggest that, as has been reported for several other bacteria studied (Jahns et al., 1988), urea uptake is subject to nitrogen control. The formation of the uptake system is repressed by ammonium, and derepression occurs in the absence of reduced nitrogen compounds.

GS and urease also turned out to be regulated by the nitrogen source supplied for growth. The regulation, however, was not strongly parallel; while urea uptake was derepressed in the absence of a fixed nitrogen source, urease exhibited only low activities (Table 5).

Thanks are due to E. F. DeLong, Woods Hole Oceanographic Institution, MA, USA, for providing reference strains of $D$. venusta, $D$. cupida and D. aesta, and to W. Gunkel for his kind invitation to use the ship 'Aade' and the facilities of the Biologische Anstalt Helgoland, FRG, for the isolation of strain D. venusta strain HGl. The author is indebted to $\mathrm{I}$. Thömmes for valuable technical assistance and to $\mathrm{G}$. Bartley for proofreading the manuscript.

\section{References}

Baumann, L., Bowditch, R. D. \& BaumanN, P. (1983). Description of Deleya gen. nov. created to accommodate the marine species Alcaligenes aestus, A. pacificus, A. cupidus, A. venustus, and Pseudomonas marina. International Journal of Systematic Bacteriology 33, 793-802.

Bender, R. A., Janssen, K. A., Resnich, A. D., Blumenberg, M., FOOR, F. \& MAGASANIK, B. (1977). Biochemical parameters of glutamine synthetase from Klebsiella aerogenes. Journal of Bacteriology 129, 1001-1009.

BertheleT, M. \& MAcLeod, R. A. (1991). The role of $\mathrm{Na}^{+}$in membrane transport and respiration in the marine bacterium Deleya aesta 134. Canadian Journal of Microbiology 37, 433-439.

COOPER, T. G. \& SUMRADA, R. (1975). Urea transport in Saccharomyces cerevisiae. Journal of Bacteriology 121, 571-576.

HERBLAND, A. (1976). In situ utilization of urea in the euphotic zone of the tropical Atlantic. Journal of Experimental Marine Biology and Ecology 21, 269-277.

JAHNS, T. \& KALTWASSER, H. (1989). Energy-dependent uptake of urea by Bacillus megaterium. FEMS Microbiology Letters 57, 13-18.

Jahns, T., Zobel, A., Kleiner, D. \& Kaltwasser, H. (1988). Evidence for carrier-mediated, energy-dependent uptake of urea in some bacteria. Archives of Microbiology 149, 377-383.

JanNSEN, D. B., Herst, P. M., Joosten, H. L. M. \& VAN DER DRIFT, C. (1981). Nitrogen control in Pseudomonas aeruginosa: a role for glutamine in the regulation of the synthesis of NADP-dependent glutamate-dehydrogenase, urease and histidase. Archives of Microbiology 128, 398-402.

JAYAKumar, A. \& BARNes, E. M. (1984). The role of glutamine in the regulation of ammonium transport in Azotobacter vinelandii. Archives of Biochemistry and Biophysics 231, 95-101.

JaYakumar, A., Hong, J.-S. \& Barnes, E. M. (1987). Feedback inhibition of ammonium (methylammonium) ion transport in Escherichia coli by glutamine and glutamine analogs. Journal of Bacteriology 169, 553-557.

Kasianowicz, J., Benz, R. \& Mclaughlin, S. (1984). The kinetic mechanism by which CCCP (carbonyl cyanide $m$-chlorophenylhydrazone) transports protons across membranes. Journal of Membrane Biology 82, 179-190.

KleINER, D. \& CASTORPH, H. (1982). Inhibition of ammonium (methylammonium) transport in Klebsiella pneumoniae by glutamine and glutamine analogues. FEBS Letters 146, 201-203.

KRISTIANSEN, S. (1983). Urea as a nitrogen source for the phytoplankton in the Oslofjord. Marine Biology 74, 17-24.

LAW, J. H. \& SLEPECKY, R. A. (1961). Assay of poly- $\beta$-hydroxybutyric acid. Journal of Bacteriology 82, 33-36.

LUND, B. A. \& BlaCKBURN, T. H. (1989). Urea turnover in a coastal marine sediment measured by a ${ }^{14} \mathrm{C}$-urea short-term incubation. Journal of Microbiological Methods 9, 297-308. 
MacLeod, R. A., Wisse, G. A. \& StejSKal, F. L. (1988). Sensitivity of some marine bacteria, a moderate halophile, and Escherichia coli to uncouplers at alkaline pH. Journal of Bacteriology 170, 4330-4337.

MCCARTHY, J. J. (1972). The uptake of urea by marine phytoplankton. Journal of Phycology 8, 216-222.

MeISTER, A. (1974). Glutamine synthetase of mammals. In The Enzymes, vol. 10, pp. 699-754. Edited by P. D. Boyer. New York \& London: Academic Press.

NIVEN, D. F. \& MACLEOD, R. A. (1980). Sodium ion-substrate symport in a marine bacterium. Journal of Bacteriology 142, 603-607.

Pateman, J. A., DunN, E. \& Mackay, E. M. (1982). Urea and thiourea transport in Aspergillus nidulans. Biochemical Genetics 20, 777-790.

PAERL, H. W. (1991). Ecophysiological and trophic implications of light-stimulated amino acid utilization in marine picoplancton. Applied and Environmental Microbiology 57, 473-479.

Rees, T. A. V., Cresswell, R. C. \& Syrett, P. J. (1980). Sodium dependent uptake of nitrate and urea by a marine diatom. Biochimica et Biophysica Acta 596, 141-144.

RemSEN, C. C. (1971). The distribution of urea in coastal and oceanic waters. Limnology and Oceanography 16, 732-740.

Remsen, C. C., Carpenter, E. J. \& SChroeder, B. W. (1974). The role of urea in marine microbial ecology. In Effect of the Ocean Environment on Microbial Activities, pp. 286-304. Edited by R. R. Colwell \& R. Y. Morita. Baltimore, London \& Tokyo: University Park Press.

SAVIDGE, G. \& Johnston, J. P. (1987). Urea degradation rates by sizefractionated plankton populations in a temperate estuary. Estuarine, Coastal and Shelf Science 24, 433-447.
Schlegel, H. G., Kaltwasser, H. \& GotTschalk, G. (1961). Ein Submersverfahren zur Kultur wasserstoffoxydierender Bakterien: Wachstumsphysiologische Untersuchungen. Archiv für Mikrobiologie 38, 208-229.

Schmidt, K., Lianen-Jensen, S. \& Schlegel, H. G. (1963). Die Carotinoide der Thiorhodaceae. I. Okenon als Hauptcarotinoid von Chromatium okenii Perty. Archiv für Mikrobiologie 46, 117-126.

SYRETT, P. J. \& BEKHEET, I. A. (1977). The uptake of thiourea by Chlorella. New Phytologist 79, 291-297.

TAGA, N. (1970). Occurrence of urea-decomposing bacteria in the neritic and oceanic waters of the northwest Pacific ocean. Proceedings of the 2nd CSK Symposium, Tokyo 253, 341-351.

Valderrama, M. J., Quesada, E., Bejar, V., Ventosa, A., GutierReZ, M. C., Ruiz-Berraguero, F. \& Ramos-Cormenzana, A. (1991). Deleya salina sp. nov., a moderately halophilic Gramnegative bacterium. International Journal of Systematic Bacteriology 41, 377-384.

Williams, S. K. \& Hudson, R. C. (1977). Transport of urea at low concentrations in Chlamydomonas reinhardtii. Journal of Bacteriology 130, 266-273.

Williamson, D. H. \& Wilkinson, J. F. (1958). The isolation and estimation of the poly- $\beta$-hydroxybutyrate inclusion bodies of Bacillus species. Journal of General Microbiology 19, 198-209.

ZAWADA, J. W. \& SUTCLIFFE, J. F. (1981). A possible role for urease as a storage protein in Aspergillus tamarii. Annals of Botany 48, 797810.

ZoBell, C. E. \& Feltham, C. B. (1935). The occurrence and activity of urea-splitting bacteria in the sea. Science 81, 234-236. 